Nova Southeastern University

From the SelectedWorks of Amanda M Foster

2019

Don't Be Distracted by the Peacock Trying to Board an Airplane: Why Emotional Support Animals Are Service Animals and Should Be Regulated in the Same Manner

Amanda M Foster

NOVA SOUTHEASTERN UNIVERSITY

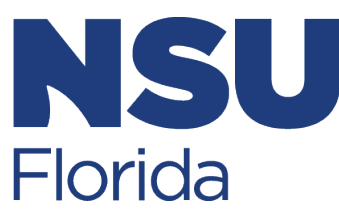

Available at: https://works.bepress.com/ 


\section{ALBANY LAW REVIEW}

Don't Be Distracted by the Peacock Trying to Board an Airplane: Why Emotional Support Animals Are Service Animals and Should Be Regulated in the Same Manner

\section{Amanda M. Foster}




\section{DON'T BE DISTRACTED BY THE PEACOCK TRYING TO BOARD AN AIRPLANE: WHY EMOTIONAL SUPPORT ANIMALS ARE SERVICE ANIMALS AND SHOULD BE REGULATED IN THE SAME MANNER.}

\section{Amanda M. Foster \\ I. INTRODUCTION}

Half of all Americans are diagnosed with a mental illness or disorder at some point in their lifetime." "Mental illnesses, such as depression, are the third most common cause of hospitalization in the United States for those aged 18-44 years old."2 In the United States, one out of ten women experience symptoms of depression. ${ }^{3}$ Further, anxiety disorders are the most prevalent mental illness in the United States. ${ }^{4}$

Despite the prevalence of mental illness, there is a societal backlash against emotional support animals whose role is to help those with mental health issues. ${ }^{5}$ Emotional support animals are used as therapy animals. ${ }^{6}$ "These support animals provide

\footnotetext{
* Associate Professor of Law, Nova Southeastern University Shepard Broad College of Law. B.A., Loyola University Maryland; J.D., Roger Williams University School of Law. Admitted to practice law in New Jersey and Pennsylvania. The author thanks Chidinma Victoria Esiobu and Hunter Rhyne for their preliminary research assistance with this piece. Many thanks to Professors Kate Webber Nuñez and Joseph Hnylka for their thoughtful readings and feedback, and Robert Beharriell, Becka Rich and Alison Rosenberg for their support as research and reference librarians at NSU Shepard Broad College of Law.

1 Mental Health: Data and Publications, Ctrs. For Disease ConTrol \& Prevention https://www.cdc.gov/mentalhealth/data_publications/index.htm (last updated Jan. 26, 2018).

${ }^{2}$ Id.

${ }^{3}$ Reproductive Health: Depression Among Women, CTRS. FOR DISEASE CONTROL \& PREVENTION, https://www.cdc.gov/reproductivehealth/depression/index.htm (last updated June 28,2018$)$.

${ }^{4}$ Facts and Statistics, ANXIETY \& DEPRESSION ASS'N OF AM., https://adaa.org/aboutadaa/press-room/facts-statistics (last visited Oct. 30, 2018).

5 See Billy Witz, Emotional Support, with Fur, Draws Complaints on Planes, N.Y. TIMES (Nov. 16, 2013), https://www.nytimes.com/2013/11/16/business/emotional-support-with-fur-dra ws-complaints-on-planes.html?_r=0.

${ }_{6}$ Jacquie Brennan \& Vinh Nguyen, Service Animals and Emotional Support Animals, ADA NAT'L NETWORK 3 (2014), https://adata.org/sites/adata.org/files/files/Service_Animal_Booklet_ 2014(2).pdf.
} 
companionship, relieve loneliness, and sometimes help with depression, anxiety, and certain phobias, but do not have special training to perform tasks that assist people with disabilities." 7 They are not considered service animals under the Americans with Disabilities Act ("ADA"), 8 which defines them as "any dog that is individually trained to do work or perform tasks for the benefit of an individual with a disability."9 Because Americans tend to treat mental health issues differently than physical, visible disabilities, ${ }^{10}$ lawmakers continue to treat emotional support animals differently than service animals. ${ }^{11}$ This different treatment is unwarranted because whether an animal is serving as a guide for someone who is visually impaired, or relieving an individual of symptoms associated with anxiety or depression, all of these things should be considered work or performing tasks. This would make service animals and emotional support animals equal players with equal protections under the ADA. Therefore, this Article suggests that the definition of service animal needs to be broadened under the ADA to include emotional support animals to provide equal treatment for individuals afflicted by all disabilities - both visible and invisible. The fact that some federal laws like the Fair Housing Act ("FHA")12 and the Air Carrier Access Act ("ACAA") ${ }^{13}$ provide for broader definitions of service animals that include emotional support animals, does not sufficiently protect people with mental health issues because those laws only provide protections in the limited housing and air travel contexts and not the context of meaningfully participating in the

7 Id.

8 See 28 C.F.R. $\S 36.104$ (2018).

9 Id.

10 See Angela M. Parcesepe \& Leopoldo J. Cabassa, Public Stigma of Mental Illness in the United States: A Systematic Literature Review, 40 Admin. Pol. Mental Health 384 (2013) (manuscript at 4), https://www.ncbi.nlm.nih.gov/pmc/articles/PMC3835659/pdf/nihms52452 7.pdf ("[C]hildren with depression or ADHD were viewed as significantly more dangerous to others and themselves as compared to children with daily troubles or children with asthma."); see also Paula M. Popovich et al., The Assessment of Attitudes Towards Individuals with Disabilities in the Workplace, 137 J. PSYCHOL. 163, 168 (2003) (physical disabilities are more often seen as disabilities in the workplace; accommodations are seen as more reasonable for physical than mental disabilities).

11 See Brennan \& Nguyen, supra note 6, at 3.

12 See U.S. Dep'T. OF Hous. \& Urban Dev., FHEO-2013-01, Service ANIMAls AND Assistance ANimals For PeOPle with Disabilities in Housing and HUD-Funded PROGRAMS 2 (2013), https://portal.hud.gov/hud-portal/documents/huddoc?id=servanimals_ntcf heo2013-01.pdf [hereinafter SERVICE ANIMALS: HoUSING].

13 See Service Animals (Including Emotional Support Animals), U.S. DEP'T OF TRANSP., https://www.transportation.gov/individuals/aviation-consumer-protection/service-animalsincluding-emotional-support-animals (last updated Mar. 20, 2018). 
general public under the ADA. ${ }^{14}$ Individuals with disabilities should not have to rely on the tenuous provisions of peripheral legislation that has been the recent subject of debate. ${ }^{15}$ Protections must be grounded in the ADA to uphold the letter and spirit of the law.

Section II of this Article provides factual background and analyzes recent incidents reported in the news about emotional support animals on mass transit, and how stereotyped reactions to them reflect mental health stigma.

Section III analyzes the practices and recommendations concerning emotional support animals in the field of psychology. Psychologists recognize the importance of emotional support animals while also recognizing the need for limits and safeguards to avoid fraud. ${ }^{16}$

Section IV of this Article provides the legal background on this issue and describes the current controversy over how to treat service animals and emotional support animals under federal law. Specifically, both the FHA and ACAA provide for broader definitions of service animals than the ADA. ${ }^{17}$ These laws, however, do not provide a comprehensive solution for protecting people with mental impairments.

The definition of service animal has been the subject of recent legislative action. ${ }^{18}$ On April 24, 2018, Senator Richard Burr (R-NC) introduced a bill to amend title 49 of the United States Code, which would make changes to the ACAA such as only allowing service animals, as defined by the ADA, to be uncaged onboard aircrafts, thereby requiring service animal behavior training for air carrier passengers and creating a criminal penalty for fraudulently claiming that an animal is a service animal used for disability needs. ${ }^{19}$ In a

14 See Kristen M. Bourland, Note, Advocating Change Within the ADA: The Struggle to Recognize Emotional-Support Animals as Service Animals, 48 U. LOUISVILLE L. REV. 197, 20203 (2009).

${ }_{15}$ See Rebecca J. Huss, A Conundrum for Animal Activists: Can or Should the Current Legal Classification of Certain Animals Be Utilized to Improve the Lives of All Animals? The Intersection of Federal Disability Laws and Breed-Discriminatory Legislation, $2015 \mathrm{MICH}$. ST. L. REV. 1561, 1588-89 (2016).

16 See Jeffrey N. Younggren et al., Examining Emotional Support Animals and Role Conflicts in Professional Psychology, 47 PROF. PSYCHOL.: RES. \& PRAC. 255, 258 (2016).

17 See SERvice Animals: Housing, supra note 12, at 2, 4; Service Animals (Including Emotional Support Animals), supra note 13.

18 See S. 2738, 115th Cong. § 1 (2018).

19 See S. 2738; Press Release, U.S. Senator Richard Burr of N.C., Senator Burr Introduces Bill to Strengthen Airline Service Animal Procedures (Apr. 24, 2018). See also 28 C.F.R. § 36.104 (2018) (defining the term "service animal," which was incorporated into S. 2738); 28 C.F.R. $\S 36.302(c)(4)(2018)$ (requiring a service animal to have a leash, harness, or tether, or be controlled by other means; by referencing this provision in S. 2738's definition of a service 
press release, while discussing the need to balance those who use service animals against those who use emotional support animals, Senator Burr stated, "[o]ne doesn't have to look far to find rampant cases of abuse where even emotional support kangaroos have been allowed to fly on planes to the detriment of fellow travelers and handlers of trained service animals." 20 The bill has been read twice and referred to the Committee on Commerce, Science, and Transportation. ${ }^{21}$

Moreover, the Department of Transportation ("DOT") is currently seeking comment on amending the ACAA's regulation on the transportation of service animals. ${ }^{22}$ The DOT wants to improve the ACAA's regulation to ensure nondiscriminatory access for individuals with disabilities to use their service animals onboard airlines while attempting to deter "fraudulent use of other animals not qualified as service animals" and prevent the use of "animals that are not trained to behave properly in the public." 23 Therefore, this Article's proposition to amend the definition of a service animal to include emotional support animals under the ADA is timely. Moreover, Senator Burr's bill and the DOT's consideration of redrafting the ACAA regulation of service animals indicate that if the ADA does not provide for a broader definition of service animals, then the current protections under the ACAA afforded to people who use emotional support animals may disappear.

Section V demonstrates that poor regulation leads to legal absurdities. Section Five of this Article therefore proposes ways to fix this ineffective regulation and treat mental and physical health equally by amending the ADA.

\section{THE PITFALLS OF INCOMPLETE LEGAL REGULATION REGARDING EMOTIONAL SUPPORT ANIMAL ACCOMMODATIONS}

Advocating for change regarding the ADA's definition of service animals is not a new topic. ${ }^{24}$ Nonetheless, there remains a need to include emotional support animals as service animals, but with careful definition of the term. This section provides examples from

\footnotetext{
animal, such animals could be uncaged onboard aircrafts).

20 See Press Release, U.S. Senator Richard Burr of N.C., supra note 19.

21 S. 2738.

22 See Traveling by Air with Service Animals, 83 Fed. Reg. 23832 (proposed May 23, 2018)

(to be codified at 14 C.F.R. pt. 382).

23. Id.

24 See, e.g., Huss, supra note 15, at 1165, 1178; Bourland, supra note 14, at 202, 203.
} 
2018 related to emotional support animals and airlines, and 2015 related to emotional support animals and malls. Because transportation companies, such as airlines, can have different policies about transporting emotional support animals, ${ }^{25}$ passengers are left to rely on their employees to explain and enforce these varying policies. ${ }^{26}$ The same is true for places of public accommodation, where users of service animals and emotional support animals must rely on the employees' understanding of whether or not animals are allowed on the premises. ${ }^{27}$ Therefore, if the ADA's definition for service animal also included emotional support animal, and that definition provided guidance as to which types of animals are covered, then these situations would not occur, or would occur less often due to more clarity. Increased clarity would also address the concerns of advocates for amending the definition in the ACAA and FHA by making it harder for abuses or fraud to occur. ${ }^{28}$ The ADA's right of individual enforcement ${ }^{29}$ also makes amending the definition in the $\mathrm{ADA}$ a stronger remedy for people with disabilities than amending the definition elsewhere.

\section{A. Leave Your Peacocks at Home}

Male peacocks have a thirty-five to fifty-inch body and a? sixty-inch

25 Compare Customers with Disabilities, SouTHweST AIRLINES, https://www.southwest.com/ $\mathrm{html} /$ customer-service/unique-travel-needs/customers-with-disabilitiespol.html?clk=GFOOTER-CUSTOMER-ASSISTANCE\#unique_travel_needs_allerg ies_disabilities_pol_tab_list_tab_10_scroll (last visited Oct. 1, 2018) ("Therapy animals, which provide affection or comfort to members of the public and are not trained to perform a specific task(s) for an individual related to a disability, may be eligible to travel in accordance with our Pet Policy for a fee."), with Flying with Service Animals \& Emotional Support Animals, DELTA AIR LINES, https://www.delta.com/us/en/accessible-travel-services/service-animals (last visited Oct. 1, 2018) ("To travel with an emotional support or psychiatric service animal, passengers must upload the required documentation at least 48 hours before a flight. . . . Advanced notice is encouraged but not required for customers travelling with trained service animals."), and Traveling with Service Animals, UNITED AIRLINES, https://www.united.com/web/en-US/content /travel/specialneeds/disabilities/assistance_animals.aspx (last visited Oct. 1, 2018) ("Therapy animals ... are not considered to be service animals. When traveling with a therapy animal, standard pet-related regulations and restrictions will apply.").

26 See, e.g., Alan Levin \& Mary Schlangenstein, Pets-on-Planes Crackdown by Airlines Gets Boost from U.S. Agency, SPOKESMAN-REVIEw (May 17, 2018), http://www.spokesman.com/stori es/2018/may/17/pets-on-planes-crackdown-by-airlines-gets-boost-fr/.

27 See Cordoves v. Miami-Dade County, 104 F. Supp. 3d 1350, 1356 (S.D. Fla. 2015); 28 C.F.R. $\$ 36.302$ (c)(6); SERVICE ANIMALS: HOUSING, supra note 12, at $2-4$.

28 See Michael Ollove, These 19 States Are Cracking Down on Fake Service Dogs, PBS NEWs Hour (Oct. 16, 2017), https://www.pbs.org/newshour/health/19-states-cracking-fake-servicedogs; A Service Dog Is More than a Vest, CANINE Companions For IndePEndence, http://www.cci.org/get-involved/advocate.html (last visited Oct. 31, 2018).

29 See Department of Justice ADA Responsibilities: ADA Enforcement, ADA.gov, https://www.ada.gov/enforce_footer.htm (last visited Oct. 31, 2018). 
train of feathers. ${ }^{30}$ They are known to have a "loud, shrill cry that can aggravate neighbors." 31 Peacocks tend to chase other creatures, including humans. ${ }^{32}$ They are known to walk up and investigate people, circle them, and peck and screech at them. ${ }^{33}$

On January 28, 2018, a woman arrived at Newark Liberty International Airport in New Jersey with what she claimed was her "emotional support peacock." 34 The New York City-based photographer and performance artist, named Ventiko, had purchased a United Airlines ticket for her peacock, Dexter, to fly with her to Los Angeles. ${ }^{35}$ Dexter was not allowed to board the United Airlines flight. ${ }^{36}$ His Instagram account indicated that, instead, he made the trip to Los Angeles via automobile. ${ }^{37}$

A United Airlines spokesperson provided the following statement: "The animal did not meet guidelines for a number of reasons, including its size and weight .... We explained this to the customer on three separate occasions before they arrived at the airport." 38

In addition to the airport, Dexter has been seen in the New York City subway. ${ }^{39}$

In March, a story entitled, After a Brush with Fame, Dexter, the Pet Peacock Who Was Refused a Seat on United, Has Moved On, was published in the Los Angeles Times. ${ }^{40}$ In the article, the author wrote: "[Ventiko and Dexter's] story set off a debate about emotional

30 Peacock, ENCYCLOPEDIA BRITANNICA, www.britannica.com/animal/peacock (last visited Oct. 31, 2018).

31 Allie Layos, 5 Essential Tips for Keeping Peacocks as Pets, WIDE OPEN PETS, www.wideopenpets.com/5-essential-tips-for-keeping-peacocks-as-pets/ (last visited Oct. 31, 2018).

${ }_{32}$ See Blake Flournoy, Reasons to Fear Peacocks, SCIEnCING, http://sciencing.com/reasonsfear-peacocks-8631075.html (last updated Aug. 23, 2018).

33 See id.

${ }^{34}$ See Woman Tries to Board Flight with a Peacock as a Comfort Animal, MSN (Jan. 31, 2018), https://www.msn.com/en-us/news/eclipse/woman-tries-to-board-flight-with-a-peacock-as -a-comfort-animal/vp-BBIuNIU.

${ }_{35}$ Woman Denied Emotional Support Peacock on United Flight, CBS NEWs (Jan. 31, 2018), www.cbsnews.com/news/woman-denied-emotional-support-peacock-on-united-flight/.

36 Id.

37 See Dexter the Peacock (@dexterthepeacock), InSTAGRAM (Jan. 27, 2018), https://instagram.com/p/BeejEFChTct/.

38 Sophie Nieto-Munoz, Emotional Support Peacock Denied Entry on United Flight Out of Newark, NJ.COM (Jan. 30,2017), www.nj.com/news/index.ssf/2018/01/emotional_support_peac ock_denied_entry_on_united_flight_out_of_newark_video.html.

39 See Dexter the Peacock (@dexterthepeacock), INSTAGRAM (June 6, 2017), https://www.inst agram.com/p/BVAlmo_Bk9L/?taken-by=dexterthepeacock.

40 See Robin Abcarian, After a Brush with Fame, Dexter, the Pet Peacock Who Was Refused a Seat on United, Has Moved On, L.A. Times (Mar. 9, 2018), www.latimes.com/local/abcarian/la -me-abcarian-peacock-20180309-story.html. 
support animals: Where is the line? Who gets to draw it?"41 Further, the article chronicles the story of how Ventiko and Dexter met. ${ }^{42}$ Ventiko was not looking for an emotional support animal.43 Instead, she was searching Craigslist ads as she prepared for Art Basel in Miami Beach, an annual international art fair. ${ }^{44}$ She wanted to add birds to her display. ${ }^{45}$ When she discovered that canaries were expensive, she opted to choose two peafowl - a male and a female for only $\$ 200.46$ After the show was over, Dexter and the female, Etta, went to live in North Port, Florida. ${ }^{47}$ They mated, and had four peachicks. ${ }^{48}$ Unfortunately, Etta and the peachicks were eaten by a predator, which caused Dexter to grieve and begin to bite. ${ }^{49}$ Instead of letting Dexter's new owner put him on the side of the road, Ventiko flew Dexter to Brooklyn, New York, in a dog kennel. ${ }^{50}$ Ventiko considered options for Dexter's future home including the Dominican Republic, but that country prohibits the importation of birds, and a family in rural Long Island who lived on a farm..$^{51}$ Dexter lived on the Long Island farm for a week and a half, but he did not do well with humans, other than Ventiko. ${ }^{52}$ When he was not allowed to travel via airplane to Los Angeles, they traveled by car. ${ }^{53}$

\section{B. A Hamster May Be Small, but It Is Not Welcome to Fly Either}

A dwarf hamster is the smallest type of hamster, with a body measuring approximately two to four inches long.54 Generally, hamsters are "solitary and primarily nocturnal" creatures. ${ }^{55}$ Although they can be nervous animals, it is possible to "train them to do tricks like retriev[e] small items." 56

In November 2017, a college student named Belen Aldecosea, who

\footnotetext{
${ }^{41} I d$.

42 See id.

43 See id.

${ }_{44} I d$.

${ }_{45} I d$.

${ }_{46} I d$.

47 Id.

${ }^{48} I d$.

49 Id.

${ }_{50} I d$.

51 Id.

${ }^{5} 2 I d$.

53 Id.

54 Guy Musser, Hamster: Rodent, ENCYCLOPEDIA BRITANNICA, https://www.britannica.com/ animal/hamster (last updated Oct. 8, 2018).

${ }_{55}$ Id.

56 See Geoff Williams, Hamster Care 101: How to Care for Your Hamster, PETMD, https://ww w.petmd.com/exotic/care/evr_ex_hm_how-to-care-for-your-hamster.
} 
was living in Philadelphia, had booked a seat on a Spirit Airlines flight from Baltimore Washington International Thurgood Marshall Airport to South Florida. ${ }^{57}$ She planned to take her emotional support dwarf hamster named Pebbles on the flight with her. ${ }^{58}$

In an article published in the Miami Herald, Ms. Aldecosea claimed that she had called Spirit Airlines twice to ensure that Pebbles could ride on the airplane with her. ${ }^{59}$ She was told that this was not a problem. ${ }^{60}$ At the airport, Ms. Aldecosea provided the airline with paperwork from her doctor regarding Pebbles' status as her emotional support animal. ${ }^{61}$ Specifically, once in Fort Lauderdale, Ms. Aldecosea was scheduled "to have a large growth removed from her neck-which is one of the reasons she got Pebbles the hamster."62

Upon her first encounter with a Spirit Airlines employee, Ms. Aldecosea did not have a problem. ${ }^{63}$ As she approached security, she came upon a second Spirit Airlines employee and was told that Pebbles was not allowed onboard. ${ }^{64}$ The airline allowed her to switch her flight from 10 a.m. to 7 p.m. so that she would have time to make other arrangements for Pebbles, but her college friends were hours away and finding transportation to get to them was an issue. ${ }^{65} \mathrm{Ms}$. Aldecosea claimed that a Spirit Airlines employee told her to flush Pebbles down an airport toilet. ${ }^{66}$ A spokesperson for Spirit Airlines denied that an employee gave such a suggestion to Ms. Aldecosea, but admitted that an employee incorrectly told her that Pebbles could travel on the airplane with her. ${ }^{67} \mathrm{Ms}$. Aldecosea stated, "[Pebbles] was scared. I was scared. It was horrifying trying to put her in the

57 See David Ovalle, Bad Info from Spirit Air Led Me to Flush Pet Hamster Down Airport Toilet, Student Says, Miami Herald (Feb. 8, 2018), https://www.miamiherald.com/news/local/c ommunity/miami-dade/article198971069.html.

58 See id.

59 See Ovalle, supra note 57.

60 See id.

61 See id.; Christal Hayes, Student Who Says She Flushed Hamster Down Toilet in Spirit Airlines Flap Has a Replacement Rodent, Lawyer Says, USA TODAY (Feb. 8, 2018), https://www.usatoday.com/story/news/2018/02/08/student-who-says-she-flushed-comforthamster-down-toilet-spirit-airlines-flap-has-replacement-rodent/320062002/. See also Witz, supra note 5 (discussing how animals such as dogs, cats, monkeys, miniature horses, and potbellied pigs are allowed on planes so long as owners have the requisite paperwork from their doctor).

62 Hayes, supra note 61.

6.3 See Ovalle, supra note 57.

64 See id.

65 See id.; Hayes, supra note 61.

66 See Ovalle, supra note 57.

67 See Hayes, supra note 61. 
toilet."68

Ms. Aldecosea is considering filing a lawsuit against Spirit Airlines. ${ }^{69}$ Her attorney compared this situation with the situation involving Dexter the peacock that occurred on United Airlines a few weeks prior. ${ }^{70}$ He claimed that there is a difference between "a giant peacock that could pose a danger to other passengers."71 At less than four inches long, a dwarf hamster, like Pebbles, fits in the palm of your hand. ${ }^{72}$

\section{JetBlue's New Policy: A Reaction to an Increase in Emotional Support Animals on Airplanes, and the Need for Clarity}

Recently, JetBlue redrafted its policy on emotional support animals. ${ }^{73}$ The policy states: "[f]or travel beginning July 1, 2018, regardless of purchase date of ticket, customers will be required to provide 48 hours' notice of their intention to travel with an emotional support or psychiatric service animal." 74 Further, the JetBlue policy defines both service animal and emotional support animal. ${ }^{75}$

68 Ovalle, supra note 57.

69 See id.

70 See id.

71 Id.

72 See id.

73 See Service and Emotional Support Animal Travel, JETBLUE, https://www.jetblue.com/atthe-airport/special-assistance/service-dogs-animals/ (last visited Nov. 3, 2018); Aaron Smith, JetBlue Tightens Policy on Emotional Support Animals, CNN BUS. (June 5, 2018), https:/money.cnn.com/2018/06/05/news/companies/jetblue-emotional-support-

animals/index.html. Southwest has also recently changed its policies regarding emotional support animals to include only dogs or cats, becoming effective on September 17, 2018. See Emotional Support Animals, SOUTHWEST, https://www.southwest.com/html/customer-service/ unique-travel-needs/customers-with-disabilities-pol.html?clk=GFOOTER-CUSTOMER-

ASSISTANCE\# visited Nov. 3, 2018); Trained Service Animals, SoUTHWEST, https:/www.southwest.com/html/c ustomer-service/unique-travel-needs/customers-with-disabilities-pol.html?clk=GFOOTER-

CUSTOMER-ASSISTANCE\#unique_travel_needs_allergies_disabilities_pol_tab_list_tab_1 0_scroll (last visited Nov. 3, 2018); see also Ben Mutzabaugh, Southwest Latest Airline to Restrict Service, Emotional Support Animals, USA TODAY (Aug. 15, 2018), https://www.usatoday.com/story/travel/flights/todayinthesky/2018/08/14/southwest-airlines-

rule-update-flying-support-animals/986458002/ "Southwest Airlines has become the latest big airline to tighten its policies on service and emotional support animals."); Lyndsey Matthews, Miniature Horses Are Allowed on Board Southwest Airlines, Per New Policy, AFAR (Aug. 17, 2018), https:/www.afar.com/magazine/miniature-horses-are-allowed-on-board-southwestairlines-per-new-policy ("[A]irlines had been updating their service animal policies to specify exactly what kind of animals are and aren't allowed on board as emotional support and service animals. . . Starting on September 17, 2018, Southwest Airlines will only allow three types of species into their cabins: dogs, cats, and miniature horses.").

74 Service and Emotional Support Animal Travel, supra note 73; see Smith, supra note 73.

75 Service and Emotional Support Animal Travel, supra note 73. 
"Animals accepted as service or emotional support animals must be providing disability mitigation directly to the customer who is traveling."76 Moreover, the policy requires that all animals, regardless of label, be trained to behave appropriately. ${ }^{77}$

The policy draws the line as to which types of animals are allowed on board-including dogs, cats, and miniature horses. ${ }^{78}$ Under federal law, both dogs and miniature horses are included in the amended definition of service animal. ${ }^{79}$ By drafting a clear policy that contains definitions and specifies types of animals allowed, JetBlue is providing an example as to how regulations can make flying a more manageable experience for both the airline and its passengers, including their animals. One down side, however, to JetBlue's policy is that people with disabilities will have less flexibility for last minute flights or flight changes than their nondisabled peers. ${ }^{80}$

\section{Dogs in Public Places: There Is Still Confusion at This Basic Level}

In 2015, a security guard asked a woman, who was shopping at a mall with her small dog in a stroller, to leave the mall. ${ }^{81}$ The woman responded that her dog was a service animal, and she refused to leave. ${ }^{82}$ Subsequently, she was arrested. ${ }^{83}$ She sued, claiming that

Service Animals: A service animal has been trained to perform a specific task to assist the customer traveling such as pathfinding, providing stability, alerting to sounds, etc.

Emotional Support Animals: An emotional support animal or psychiatric service animal provides comfort to support a customer's diagnosed mental or emotional disorder. Emotional support animals need not have specific training for that function, while psychiatric service animals are task trained. All must be trained to behave appropriately in a public setting. Acceptable emotional support and psychiatric service animals are limited to dogs, cats, and miniature horses. Your animal must behave appropriately in a public setting and have required documentation as noted below.

Id. Placement?

76 Id.

77 See id.

78 See id.

79 See U.S. Dep't of Justice: Civil Rights Div., ADA 2010 Revised Requirements: SERVICE ANIMALS 1-3 (2011) [hereinafter ADA REQUIREMENTS: SERVICE ANIMALS].

80 See Service and Emotional Support Animal Travel, supra note 73. (Policy allows individuals with service animals to purchase additional seats or wait for an additional flight, which will deplete the airlines flexibility in making similar arrangements for individuals with disabilities).

81 See Cordoves v. Miami-Dade Cty., 104 F. Supp. 3d 1350, 1355 (S.D. Fla. 2015).

82 See id.

83 Id. 
she was discriminated against in violation of the ADA. ${ }^{84}$ She provided the following information to the court: (1) letters from a physician who had prescribed a service animal for the plaintiff and a letter from plaintiff's treating physician; (2) the dog attended obedience, service and therapy training through Breed Master Dog Training, and she had a letter from that trainer; and (3) the task associated with this dog was called "pre-alert task," which is a task associated with alerting the individual with disabilities regarding, for example, PTSD. ${ }^{85}$ Defendants argued that the plaintiff's witness was not qualified to give expert testimony about whether the dog was a service animal. ${ }^{86}$ The court agreed with the defendants because the witness admitted that he was not an animal trainer and had never trained a service animal. ${ }^{87}$ Nonetheless, the Cordoves v. Miami-Dade County case indicates that confusion in the community still exists - both amongst employees in places of public accommodation and people claiming to use service animals-about which animals qualify as a service animal.

\section{E. Crafting Our Way Out of the Confusion}

These four examples illustrate the difficulties surrounding the determination of which animals are protected under federal law, which animals are not protected under federal law, and which federal law is applicable to the specific scenario at hand. Clearly, Dexter the peacock was not an emotional support animal. He was merely a pet. 88 Drafting a clear law that specifically excludes pets is not a problem.

The hamster case is a bit trickier. Here, the hamster was an emotional support animal, prescribed by a doctor, and used specifically to help an individual dealing with a medical situation, i.e., removal of a growth in her neck. ${ }^{89}$ When crafting a definition of service animal and including emotional support animals, it may be necessary to provide a list of species or breeds of animals that are

$84 I d$.

85 See id. at 1361. See Kylena Boka, Alerting: Everything You Need to Know, Serv. DoG Soc'Y, https://www.servicedogsociety.com/alerting/ (last visited Nov. 3, 2018) ("Medical alter is arguably the fastest growing category of service dog.").

86 See Cordoves, 104 F. Supp. 3d at 1357.

87 See id. at 1358.

88 Compare Abcarian, supra note 40 (Ventiko purchased Dexter because she wanted to "garnish" her art piece with birds), with Ovalle, supra note 57 (Aldecosea purchased Pebbles because she was alone and had developed a golf-ball size growth on her neck causing a cancer scare).

89 See Ovalle, supra note 57. 
acceptable..$^{90}$ If members of the rodent family are excluded, then someone with an emotional support hamster would need to find a different, appropriate animal. When thinking about rodents, a hamster may be an allowable animal while still excluding other rodents. This example illustrates the attention to detail necessary for properly crafting the definition of service animal.

The redrafted JetBlue policy is an example that legislators can look to when deciding how to redraft the definition of service animal under the ADA. The phrase "providing disability mitigation directly to the customer who is traveling" clearly excludes pets. ${ }^{91}$ Similarly, providing a list of acceptable animals decreases the confusion of which animals are allowed onboard the aircraft..$^{92}$

Finally, the Cordoves case is an example that shows a user of a dog-an animal specifically included in the definition of service animal-in a public place may still be discriminated against because an employee is unsure as to whether the dog is a service animal, an emotional support animal, or a pet. ${ }^{93}$ Providing employees in places of public accommodation with a clear definition will take some of the guess-work out of these scenarios.

\section{EMotional SUPPORT ANIMALs PROVIDE RECOGNIZED PSYCHOLOGICAL TREATMENT}

In 2017, the American Veterinary Medical Association ("AVMA"), published a peer-reviewed whitepaper entitled, Assistance Animals: Rights of Access and the Problem of Fraud, stating that emotional support animals "serve a purpose in mitigating psychological disorders, but are not currently defined as service animals by the ADA."94 It labeled service animals and emotional support animals as "assistance animals" because they both "accompany their handler and assist him or her." 95 The whitepaper focused on the need for "clear and consistent definitions" related to service animals. ${ }^{96}$ "Because psychological disorders do not only occur at home or on

\footnotetext{
90 See, e.g., Service and Emotional Support Animal Travel, supra note 73 (providing dogs, cats, and miniature horses as "accepted" emotional support animals and criteria for animals the airline does not consider emotional support animals).

${ }_{91} I d$.

92 See id.

93 See Cordoves v. Miami-Dade Cty., 104 F. Supp. 3d 1350, 1355 (S.D. Fla. 2015).

94 AM. VETERINARY MED. ASS'N, ASSISTANCE ANIMALS: RIGHTS OF ACCESS AND THE PROBLEM OF FRAUD 1, 2 (2017), https://www.avma.org/KB/Resources/Reports/Documents/Assistance-Ani mals-Rights-Access-Fraud-AVMA.pdf.

95 Id.

96 See id. at 13.
} 
airplanes, a case can be made that [emotional support animals] should be allowed to accompany their handlers in public areas." 97

Many psychologists are using emotional support animals in clinical settings because of the increasing belief that there are therapeutic benefits to including these animals in sessions. ${ }^{98}$ For example, emotional support animals have been used in animal-assisted therapy ("AAT") with veterans suffering from post-traumatic stress disorder ("PTSD").99 AAT is defined as "any intervention that intentionally includes or incorporates animals as part of a therapeutic or ameliorative process or milieu."100 There is support that AAT is beneficial to veterans suffering from PTSD because it provides companionship. ${ }^{101}$ In addition, "dogs [can] become surrogate attachment figures in their owners' lives" with a bond between owner and animal that is "similar in strength to the psychological bond that forms between human dyads."102

Although recognizing the importance of emotional support animals, the psychological community also recognizes the need for limits and safeguards to avoid fraud.103 In an article entitled, Examining Emotional Support Animals and Role Conflicts in Professional Psychology, the authors examine "the role conflicts that psychologists may face in their practices related to the evaluation and certification of emotional support animals."104 Today, many psychologists have patients who are asking them "to certify their need to have [an emotional support animal] in settings where the presence of the animal had previously been prohibited."105 The conflict arises when the psychologist has to be both the treating professional and the evaluator of need, which entails providing information to others. ${ }^{106}$

Nonetheless, if having an emotional support animal is part of the psychologist's treatment plan for the patient, then the treating psychologist may have a role in writing a letter of evaluation and

97 Id. at 15.

98 See Jeffrey N. Younggren et al., Examining Emotional Support Animals and Role Conflicts in Professional Psychology, 47 PROF. PSYCHOL. 255, 257 (2016).

99 See Myra F. Taylor et al., "Nudging Them Back to Reality": Toward a Growing Public Acceptance of the Role Dogs Fulfill in Ameliorating Contemporary Veterans' PTSD Symptoms, 26 ANTHROZOÖS 593, 595 (2013).

$100 \mathrm{Id}$.

101 See id.

102 Id.

103 See Younggren et al., supra note 98, at 258-59.

104 Id. at 255 .

$105 \mathrm{Id}$.

106 See id. 
certification of their animal as an emotional support animal. ${ }^{107}$ "[I]n some states it is actually a crime to certify fraudulently an animal as a s[ervice] a[nimal] or an e[motional] s[upport] a[nimal]."108 In addition, a psychologist could be disciplined by the state's board of psychology. ${ }^{109}$

The AVMA noted that part of the problem with fraud is "the lack of a centralized or standardized form of proof that can be used to ascertain an assistance animal's status." 110 A market has sprung up to falsely certify pets as emotional support animals. ${ }^{111}$ Creating clear and consistent definitions regarding animals, cracking down on the availability of fraudulent materials available to the public, and improving access for companion animals in public are all suggestions proposed by the AVMA on how to deal with reducing fraud. ${ }^{112}$ These measures should be included in any new proposed regulations or statutory changes.

\section{LEGAL BACKGROUND ON SERVICE AND EMOTIONAL SUPPORT ANIMALS}

There are multiple federal laws in place that provide clear protection for service animals including the ADA, the FHA, and the ACAA. ${ }^{113}$ Nonetheless, lawmakers have refused to recognize the similar and important role of emotional support animals. ${ }^{114}$ As a result of legislators' choice not to capture emotional support animals under the category of service animals, individuals with invisible mental health issues are forced to deal with a different set of rules, or even discriminatory actions against them. ${ }^{115}$ Continuing to treat emotional support animals differently than service animals means

\footnotetext{
107 See id. at 258.

108 Id.

109 See id.

110 AM. VETERINARY MED. Ass'N, supra note 94, at 3.

111 See id. at 11.

112 See id. at $13-15$.

113 See Tiffany Lee, Criminalizing Fake Service Dogs: Helping or Hurting Legitimate Handlers?, 23 ANIMAL L. 325, 328 (2017); see, e.g., American's With Disabilities Amendments Act of 2008, 42 U.S.C. $\$ 12101$ (2017); Fair Housing Act, 42 U.S.C. $\$ 3601$ (2017); Air Carrier Access Act, 49 U.S.C. $\$ 41705$ (2017).

114 See Lee, supra note 113, at 331.

115 Compare id. at 333 ("Under the ACAA, psychiatric service animals are subject to increased documentation and advance notification requirements not required for other types of service animals."), with id. ("[While, f]or the purposes of the FHA, a service animal is defined as 'an animal that works, provides assistance, or performs tasks for the benefit of a person with a disability, or provides emotional support that alleviates one or more identified symptoms or effects of a person's disability."').
} 
that their important role in the healthcare context is being ignored. ${ }^{116}$

\section{A. The Americans with Disabilities Act}

In 1990, Congress enacted the ADA "to provide a clear and comprehensive national mandate for the elimination of discrimination against individuals with disabilities." 117 On the day that President George H.W. Bush signed the ADA into law, he remarked that " $[w]$ ith today's signing of the landmark Americans [with] Disabilities Act, every man, woman, and child with a disability can now pass through once-closed doors into a bright new era of equality, independence, and freedom." 118

The ADA prohibits the discrimination of individuals on the basis of disability in regard to "the full and equal enjoyment of the goods, services, facilities, privileges, advantages, or accommodations of any place of public accommodation by any person who owns, leases (or leases to), or operates a place of public accommodation."119 Further, the ADA prohibits:

[A] failure to make reasonable modifications in policies, practices, or procedures, when such modifications are necessary to afford such goods, services, facilities, privileges, advantages, or accommodations to individuals with disabilities, unless the entity can demonstrate that making such modifications would fundamentally alter the nature of such goods, services, facilities, privileges, advantages, or accommodations. ${ }^{120}$

Malls, grocery stores, movie theaters, restaurants, and terminals

116 See Bourland, supra note 14, at 205.

11742 U.S.C. $\S 12101(\mathrm{~b})(1)$. Congress, in enacting the ADA, specifically "used its power under the Commerce Clause and the Fourteenth Amendment." Elizabeth A. Pendo, Disability, Doctors, and Dollars: Distinguishing the Three Faces of Reasonable Accommodation, 35 U.C. DAVIS L. REV. 1175, 1178 (2002). And while the ADA is both structurally and substantively based on Title VII of the Civil Rights Act of 1964, Title I of the ADA added an additional form of discrimination: "not making reasonable accommodations to the known physical or mental limitations of an otherwise qualified individual with a disability." 42 U.S.C. $\S 12112(\mathrm{~b})(5)(\mathrm{A})$ (2017) (emphasis added); Pendo, supra note 117, at 1179.

118 George H. W. Bush, Remarks of President Bush at the Signing of the American with Disabilities Act, U.S. EQUAL EMP'T OPPORTUNITY COMM'N, http://www.eeoc.gov/eeoc/history/35t h/videos/ada_signing_text.html (last visited Nov. 3, 2018); see Amanda M. Foster, Reasonable Accommodations on the Bar Exam: Leveling the Playing Field or Providing an Unfair Advantage?, 48 VAL. U. L. REV. 661, 663 (2014).

11942 U.S.C. § 12182(a) (2018).

120 Id. at $\S 12182(\mathrm{~b})(2)(\mathrm{A})(\mathrm{ii})$. 
for public transportation are all examples of places of public accommodation subject to the ADA if the operations of these entities affect commerce. ${ }^{121}$ Employees of places of public accommodation are only permitted to make two inquiries as to whether an animal qualifies as a service animal. ${ }^{122}$ First, a public accommodation may ask "if the animal is required because of a disability."123 Second, a public accommodation may ask "what work or task the animal has been trained to perform." 124

The ADA itself does not mention either service animals or emotional support animals in the text of the statute. ${ }^{125}$ The term "service animal" is defined in the regulations that implement the ADA. ${ }^{126}$ Specifically, a service animal means: "any dog that is individually trained to do work or perform tasks for the benefit of an individual with a disability, including a physical, sensory, psychiatric, intellectual, or other mental disability."127 Further, "[o]ther species of animals, whether wild or domestic, trained or untrained, are not service animals for the purposes of this definition." 128

The concepts of work and tasks are important pieces included in the definition of service animal. ${ }^{129}$ "The work or tasks performed by a service animal must be directly related to the individual's disability."130 The Code of Federal Regulations ("CFR") provides examples of work or tasks. ${ }^{131}$ Specifically, work or tasks include, but are not limited to:

[A]ssisting individuals who are blind or have low vision with navigation and other tasks, alerting individuals who are deaf or hard of hearing to the presence of people or sounds, providing non-violent protection or rescue work, pulling a wheelchair, assisting an individual during a seizure, alerting individuals to the presence of allergens, retrieving items such as medicine or the telephone, providing physical support and

\footnotetext{
121 See id. $\S 12181(7)$.

122 Cordoves v. Miami-Dade Cty., 104 F. Supp. 3d 1350, 1356 (S.D. Fla. 2015).

${ }_{123}$ Id. (quoting 28 C.F.R. $\S 36.302(c)(6)$ ).

124 Cordoves, 104 F. Supp. 3d at 1356 (quoting 28 C.F.R. $\S 36.302(\mathrm{c})(6)$ ).

125 See Cordoves, 104 F. Supp. 3d at 1355; 42 U.S.C. $§ 12101$ (2008).

12628 C.F.R. $\$ 36.104$ (2016).

127 Id. (emphasis added).

128 Id.

129 See id.

${ }_{130} I d$.

131 See id.
} 
assistance with balance and stability to individuals with mobility disabilities, and helping persons with psychiatric and neurological disabilities by preventing or interrupting impulsive or destructive behaviors. ${ }^{132}$

Finally, the CFR states: "[t]he crime deterrent effects of an animal's presence and the provision of emotional support, well-being, comfort, or companionship do not constitute work or tasks for the purposes of this definition." 133

The Department of Justice ("DOJ") has published a guidance document on service animals. ${ }^{134}$ Referring to the CFR, "miniature horses that have been individually trained to do work or perform tasks for people with disabilities" are included in revised ADA regulations. ${ }^{135}$

Entities covered by the ADA must modify their policies to permit miniature horses where reasonable. The regulations set out four assessment factors to assist entities in determining whether miniature horses can be accommodated in their facility. The assessment factors are (1) whether the miniature horse is housebroken; (2) whether the miniature horse is under the owner's control; (3) whether the facility can accommodate the miniature horse's type, size, and weight; and (4) whether the miniature horse's presence will not compromise legitimate safety requirements necessary for safe operation of the facility. ${ }^{136}$

Further, the DOJ has addressed emotional support, therapy, comfort, or companion animals in its Frequently Asked Questions section of the guidance document. ${ }^{137}$ In that section, the DOJ states that these animals are not considered service animals under the ADA

\footnotetext{
$132 I d$.

133 Id.

134 See ADA REQUIREMENTS: SERVICE ANIMALs, supra note 79, at 1 ("The Department of Justice published revised final regulations implementing the Americans with Disabilities Act (ADA) for title II (State and local government services) and title III (public accommodations and commercial facilities) on September 15, 2010, in the Federal Register. These requirements, or rules, clarify and refine issues that have arisen over the past 20 years and contain new, and updated, requirements, including the 2010 Standards for Accessible Design (2010 Standards).").

135 Id. at 3; 28 C.F.R. § 36.302(c)(9) (2016).

136 ADA REQUIREMENTS: SERVICE ANIMALS, supra note 79, at 3.

137 U.S. DeP'T OF Justice: Civil Rights Div., FrEquently ASKed QueSTIONS ABout SERVICE ANIMALS AND THE ADA, (2015) [hereinafter FAQ ABOUT SERVICE ANIMALS].
} 
because "they have not been trained to perform a specific job or task."138 On the other hand, psychiatric support animals, who have been trained to deal with specific health issues, e.g., an anxiety attack, are considered to be service animals under the ADA due to their training. ${ }^{139}$ For example, if a dog is trained to prevent or interrupt a person's "impulsive or destructive behaviors," then it is considered a service animal. ${ }^{140}$

Moreover, the CFR addresses nondiscrimination on the basis of disability in state and local government services. ${ }^{141}$ It includes the following: "[g]enerally, a public entity shall modify its policies, practices, or procedures to permit the use of a service animal by an individual with a disability." 142 The exception to this rule is that "[a] public entity may ask an individual with a disability to remove a service animal from the premises if - (1) [t] he animal is out of control and the animal's handler does not take effective action to control it; or (2) [t]he animal is not housebroken."143 This is similar to the DOJ regulation on nondiscrimination in commercial facilities. ${ }^{144}$

The current regulations reflect changes the DOJ proposed in 2010 in an attempt to clarify the definition of service animals and address public concerns. ${ }^{145}$ Published on September 15, 2010, and effective on March 15, 2012, the Appendices following Parts 35 and 36 of Guidance on Revisions to the ADA Regulation on Nondiscrimination on the Basis of Disability in State and Local Government Services and Public Accommodations and Commercial Facilities, provide public comments and responses from the DOJ as they were developing these regulations. ${ }^{146}$ The DOJ explained why it was considering changing the definition of "service animal" and addressed concerns from the public. ${ }^{147}$ The DOJ stated that the definition of

\footnotetext{
138 Id. (emphasis added).

139 See id.

14028 C.F.R. $\$ 36.104$ (2016).

14128 C.F.R. $\$ 35.136(2011)$.

142 Id.

143 Id.

144 Compare 28 C.F.R. $§ 35.136$ (2011) ("Generally, a public entity shall modify its policies, practices, or procedures to permit the use of a service animal by an individual with a disability."), with 28 C.F.R. § 36.302(c) (2016) (“Generally, a public accommodation shall modify policies, practices, or procedures to permit the use of a service animal by an individual with a disability.").

145 See 28 C.F.R. pt. 35, app. A (2010) ("[T]he Department proposed to modify the definition of service animal, added the definition to title II, and asked for public input on several issues related to the service animal provisions of the title II regulation."); 28 C.F.R. pt. 36, app A (2010).

146 See 28 C.F.R. pt. 35, app. A; 28 C.F.R. pt. 36, app. A.

147 See 28 C.F.R. pt. 35, app. A; 28 C.F.R. pt. 36, app. A.
} 
service animal was clarified because "[m]any covered entities indicated that they are confused regarding their obligations under the ADA with regard to individuals with disabilities who use service animals." 148 The DOJ noted that "[i]ndividuals with disabilities who use trained guide or service dogs are concerned that if untrained or unusual animals are termed 'service animals,' their own right to use guide or service dogs may become unnecessarily restricted or questioned."149 In addition, there is a fear of individuals fraudulently labeling their pet as a service animal "to gain access to courthouses, city or county administrative offices, and other title II facilities." 150 Further, the DOJ noted that an increase in the "use of wild, exotic, or unusual species, many of which are untrained, as service animals has also added to the confusion." 151 The guidance on miniature horses, an expansion from the original regulation which only allowed dogs, ${ }^{152}$ shows that the DOJ is open to expanding the definition as the science on which animals are useful as service animals increases. Accommodating people with psychiatric disabilities in the regulations should take into account the concerns raised by those who use service animals. As the stigma following people with psychiatric disabilities decreases and the science on emotional support animals increases, support for changing the regulations in their favor is likely to increase. Nonetheless, as discussed in Section Five of this article, clarifying the confusion has not been fully successful, and the confusion remains.

\section{B. Fair Housing Act}

In 1968, Congress enacted the FHA to prohibit discrimination in the purchase or rental of housing. ${ }^{153}$ Similar to the ADA, the FHA does not define "service animal" or "emotional support animal" in the text of the statute. ${ }^{154}$ In 1988, Congress amended the FHA to include "handicap" as a protected class. ${ }^{155}$ The definition reads:

14828 C.F.R. pt. 35 , app. A

149 Id.

$150 \mathrm{Id}$.

151 Id.

152 See id. ("The traditional service animal is a dog[.]").

153 See 42 U.S.C. $\$ 3604$ (2012) ("I]t shall be unlawful . . . [t]o discriminate in the sale or rental, or to otherwise make unavailable or deny, a dwelling to any buyer or renter because of handicap of-that buyer or renter[.]").

154 See id. $\$ 3602$.

155 Fair Housing Amendments Act of 1988, Pub. L. No. 100-430, § 5(b), 102 Stat. 1619 (1988). 
(h) "Handicap" means, with respect to a person-

(1) a physical or mental impairment which substantially limits one or more of such person's major life activities,

(2) a record of having such an impairment, or

(3) being regarded as having such an impairment. ${ }^{156}$

The FHA's definition of handicap mirrors the ADA's definition of disability. ${ }^{157}$

The Secretary of Housing and Urban Development ("HUD") controls the administration of the FHA.158 "A plaintiff may prove discrimination under the FHA by showing the failure to provide a reasonable accommodation." 159 Housing discrimination is defined in the FHA as refusing to "make reasonable accommodations in rules, policies, practices, or services, when such accommodations may be necessary to afford such person equal opportunity to use and enjoy a dwelling." 160

In the housing context, a reasonable accommodation could be the waiver of a no pet policy to allow an emotional support animal. ${ }^{161}$ For example, in the case of Janush v. Charities Housing Development Corporation, ${ }^{162}$ plaintiff's treating psychologist testified that she had a severe mental health disability and that her pets - two birds and two cats - decreased the effects of her disability because they provided companionship and were necessary to her mental health. ${ }^{163}$ Plaintiff signed a lease and moved into her apartment without asking the landlord to allow her pets. ${ }^{164}$ Subsequently, plaintiff was evicted and sued alleging discrimination based on the defendants' refusal to provide her with a reasonable accommodation in violation of the FHA. ${ }^{165}$ Defendants moved to dismiss. ${ }^{166}$ The court held that "[e]ven

15642 U.S.C. $\S 3602(\mathrm{~h})$.

157 See id.; 42 U.S.C. $§ 12102(1)(2012)$

15842 U.S.C. $\S 3608$ (a) (1988).

159 Rebecca J. Huss, Why Context Matters: Defining Service Animals Under Federal Law, 37 PEPP. L. REV. 1163, 1194 (2010).

16042 U.S.C. $\S 3604(\mathrm{f})(3)(\mathrm{B})(2012)$.

161 See 24 C.F.R. § 100.204(b)(1) (1989). HUD provides an example of reasonable accommodation: "A blind applicant for rental housing wants live in a dwelling unit with a seeing eye dog. The building has a no pets policy. It is a violation of $\S 100.204$ for the owner or manager of the apartment complex to refuse to permit the applicant to live in the apartment with a seeing eye dog because, without the seeing eye dog, the blind person will not have an equal opportunity to use and enjoy a dwelling." Id.

162 Janush v. Charities Hous. Dev. Corp., 169 F. Supp. 2d 1133 (N.D. Cal. 2000).

163 Id. at 1134.

164 Id.

165 Id. at 1134-35.

166 Id. at 1135. 
if plaintiff's animals do not qualify as service animals, defendants have not established that there is no duty to reasonably accommodate non-service animals."167 Further, plaintiff adequately pleaded that she was handicapped, "that defendants knew of her handicap, that accommodation of the handicap may be necessary and that defendants refused to make such accommodation."168 Therefore, the court denied the motion to dismiss. ${ }^{169}$

\section{Airline Carrier Access Act and Airline Regulations}

The ACAA, a federal law, applies to all U.S. airlines. ${ }^{170}$ In addition, it applies to foreign airlines that have flights that start or terminate at a U.S. airport. ${ }^{171}$ The Act prohibits airlines from discriminating against air passengers with disabilities-whether physical, mental, or both-who travel with service animals. ${ }^{172}$

Moreover, the ACAA requires airlines to accept emotional support animals with a note from a doctor or a licensed therapist. ${ }^{173}$ Specifically, "[i]f a passenger seeks to travel with an animal that is used as an emotional support or psychiatric service animal, [the airlines] are not required to accept the animal for transportation in the cabin unless the passenger provides... current documentation."174 This documentation must be "no older than one year from the date of the passenger's scheduled initial flight" and "on the letterhead of a licensed mental health professional (e.g., psychiatrist, psychologist, licensed clinical social worker, including a medical doctor specifically treating the passenger's mental or emotional disability)." ${ }^{175}$ The documentation must include the following:

(1) The passenger has a mental or emotional disability recognized in the Diagnostic and Statistical Manual of Mental Disorders-Fourth Edition (DSM IV);

(2) The passenger needs the emotional support or psychiatric

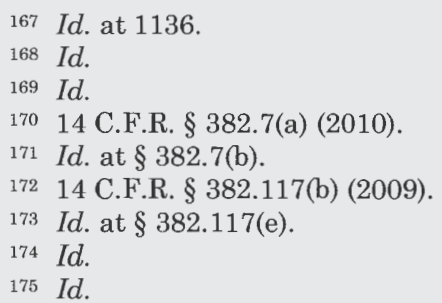


service animal as an accommodation for air travel and/or for activity at the passenger's destination;

(3) The individual providing the assessment is a licensed mental health professional, and the passenger is under his or her professional care; and

(4) The date and type of the mental health professional's license and the state or other jurisdiction in which it was issued. ${ }^{176}$

"The U.S. Department of Transportation ["DO'T'] is seeking comment on amending the [ACAA] regulation on transportation of service animals." 177 The summary of the Advance Notice of Proposed Rulemaking reads as follows:

The [DOT] has heard from the transportation industry, as well as individuals with disabilities, that the current ACAA regulation could be improved to ensure nondiscriminatory access for individuals with disabilities, while simultaneously preventing instances of fraud and ensuring consistency with other Federal regulations. The Department recognizes the integral role that service animals play in the lives of many individuals with disabilities and wants to ensure that individuals with disabilities can continue using their service animals while also helping to ensure that the fraudulent use of other animals not qualified as service animals is deterred and animals that are not trained to behave properly in the public are not accepted for transport as service animals. ${ }^{178}$

The deadline to submit comments was July 9, 2018. ${ }^{179}$ Over 3,000 comments were received. ${ }^{180}$

The ACAA's current service animal requirements are significantly broader than the ADA and the FHA. ${ }^{181}$ Specifically, the ACAA allows

176 Id.

177 Traveling by Air With Service Animals, 83 Fed. Reg. 23,832 (proposed May 23, 2018) (to be codified at 14 C.F.R. pt. 382).

$178 I d$.

179 Id. at 23,842 .

180 Id., available at https://www.federalregister.gov/documents/2018/05/23/2018-10815/trav eling-by-air-with-service-animals.

181 Compare Traveling by Air With Service Animals, 83 Fed. Reg. at 23,834-35 (indicates that the ACAA defines service animal as "any animal."), with 28 C.F.R. 36.104 (2016) (indicates that service animal only applies to dogs), and 24 C.F.R. $\S 100.204(\mathrm{~b})(1)$ (1989) (provides an example of a blind tenant being able to have a seeing-eye dog). 
"a service animal to be any animal that is individually trained to assist a qualified person with a disability or any animal necessary for the emotional well-being of a passenger."182 Therefore, the airlines treat emotional support animals as service animals, but requires that emotional support animal and psychiatric support animal users "provide] [the airline] current documentation (i.e., no older than one year from the date of the passenger's scheduled initial flight) on the letterhead of a licensed mental health professional."183 The DOT"s "disability rule permits airlines not to transport service animals that pose a direct threat to the health or safety of others or would cause a significant disruption of cabin service."184 The DOT has provided guidance to airlines regarding the behavior of service animals. ${ }^{185}$ Specifically, an animal, if properly trained, should not run freely, bark or growl at other persons, urinate or defecate in the gate area, or bite. ${ }^{186}$ An animal should remain calm while with its owner. ${ }^{187}$

The DOT receives complaints regarding service animals. ${ }^{188}$ For example, "[i]n 2016, the third highest disability complaint area concerned service animals, and in 2017, it was the fifth highest."189 The majority of service animal complaints that involve emotional support animals or psychiatric support animals revolve around "passengers with disabilities who are upset that the airline is not accepting their animals for transport." 190

In 2009, "[t]he Psychiatric Service Dog Society (PSDS), an advocacy group representing users of psychiatric service dogs, petitioned the [DOT] . . . to eliminate the [ACAA] regulation that permitted airlines to require documentation and 48 hours' advance notice for users of psychiatric service animals." 191 The PSDS contended that the DOT was "discriminating against and stigmatizing individuals with mental health-related disabilities who use [psychiatric service animals]" because service animal users with physical disabilities were not being treated in the same manner. ${ }^{192}$ Subsequently, the DOT received a request from Airlines for America to initiate

\footnotetext{
182 Traveling by Air With Service Animals, 83 Fed. Reg. at 23,833.

183 14 C.F.R. \& 382.117(e) (2009).

184 Traveling by Air With Service Animals, 83 Fed. Reg. at 23,833.

18.5 See Nondiscrimination on the Basis of Disability in Air Travel, 73 Fed. Reg. 27,614, 27,659 (May 13, 2008) (to be codified at 14 C.F.R. pt. 382).

186 Id.

187 See id.

188 See Traveling by Air With Service Animals, 83 Fed. Reg. at 23,834.

189 Id.

$190 \mathrm{Id}$.

191 Id. at 23,835 .

192 Id.
} 
rulemaking to amend its service animal regulation. ${ }^{193}$ Airlines for America seeks to harmonize the DOT's definition of service animal with the ADA's definition of service animal. ${ }^{194}$ Further, Airlines for America wants to limit the types of emotional support animals and psychiatric support animals on airlines. ${ }^{195}$ Comments were received, and a number of issues are explored in this rulemaking. ${ }^{196}$

In 2016, the DOT established an Advisory Committee on Accessible Air Transportation to address, among other things, the development of a proposed rule regarding service animals. ${ }^{197}$ Unfortunately, the Advisory Committee was unable to "reach consensus on how the service animal regulations should be revised."198 Nonetheless, the information gathered during their process is useful for trying to solve the current issues.

First, airlines are objecting to recognizing emotional support animals as service animals in the context of the ACAA because they are not treated the same under the ADA. ${ }^{199}$

Five disability organizations [including] Psychiatric Service Dog Partners, Guide Dog Foundation for the Blind, Open Doors Organization, National Multiple Sclerosis Society, and Guide Dog Users, Inc.] proposed limiting e[motional] s[upport] a[nimals] on airlines to dogs, cats, and rabbits and requiring that they be contained in approved pet carriers, except when needed for disability mitigation. ${ }^{200}$

This is similar to the concerns raised in the commentary to the 2010 changes to the definition of service animal under the ADA. ${ }^{201}$ Six other disability organizations were in favor of adding household

193 See Traveling by Air with Service Animals, 83 Fed. Reg. at 23,835; Letter from Sharon L. Pinkerton, Senior Vice President, Airlines for Am., to James Owens, Deputy Gen. Counsel, Dep't of Transp. (Jan. 31, 2018), https://www.regulations.gov/document?D=DOT-OST-20150246-0314.

${ }_{194}$ Traveling by Air With Service Animals, 83 Fed. Reg. at 23,835.

195 Id.

196 See id.

197 Id. at $23,835-36$.

198 Id. at 23,836 .

199 See id.

$200 \mathrm{Id}$.

201 Compare Nondiscrimination on the Basis of Disability by Public Accommodations and in Commercial Facilities, 75 Fed. Reg. 56,236, 56,267 (July 10, 2010) (to be codified at 28 C.F.R. pt. 36) (discussing that commentators have suggested limiting the number of allowable species), with Traveling by Air With Service Animals, 83 Fed. Reg. at 23,836 (discussing suggestions by several entities to limit the allowable species on airlines). 
birds to that list. ${ }^{202}$ Airlines and flight attendants would like the DOT to require that all emotional support animals be required to stay in pet carriers throughout the duration of the flight. ${ }^{203}$

\section{Proposed Regulation and the Potential Fallout}

Differing definitions breeds differing understandings. Society's inability to distinguish between a service animal, a psychiatric service or support animal, an emotional support animal, or a therapy animal means that persons with disabilities will continue to be discriminated against in the context of using their animals to assist them with their disabilities, physical and mental, visible and invisible.

As a starting point, the definition of service animal under the ADA must be amended to provide protection for individuals using emotional support animals. This would bring about parity between those with physical or mental disabilities. Service animals are already allowed in places of public accommodation. ${ }^{204}$ Extending the definition to include emotional support animals does not change the fact that animals are already in these places. It merely provides users of emotional support animals with the same protections in places of public accommodation, which are already afforded to users of service animals, so long as the animal does not constitute a direct threat. ${ }^{205}$ Moreover, both the FHA and the ACAA already recognize the need to protect individuals' rights to use their emotional support animals in housing and air travel. ${ }^{206}$

Specifically, in 2013, HUD issued a notice regarding the use of the word "assistance animal" instead of "service animal."207 Under the FHA, assistance animal is "an animal that works, provides assistance, or performs tasks for the benefit of a person with a disability, or provides emotional support that alleviates one or more identified symptoms or effects of a person's disability."208 There is no requirement for training and, while dogs are the most common type

202 Traveling by Air With Service Animals, 83 Fed. Reg. at 23,836.

$203 I d$.

20428 C.F.R. $\S 35.136$ (2011).

205 See Day v. Sumner Reg'l Health Sys., Inc., No. 3:07-0595, 2007 WL 4570810, at *3 (M.D.

Tenn. Dec. 26, 2007) (holding that it was not a direct threat to allow a service animal to be in a medical treatment area).

206 See SERvice AnIMALS: Housing, supra note 12, at 2; Traveling by Air With Service Animals, 83 Fed. Reg. at 23,833.

207 See SERVICE ANIMALS: HousING, supra note 12 , at 2 n.4.

208 Id. at 2. 
of assistance animal, people are not prohibited from using other types of animals. ${ }^{209}$ Therefore, this definition illustrates that (1) the concept of a service animal has evolved over time to now become an assistance animal; (2) it is possible to craft a definition that encompasses both the typical service animal and an emotional support animal under the same umbrella; and (3) there is a societal need for this type of change under federal law, so that all persons with disabilities have the opportunity to use animals to assist, alleviate, and or mitigate the symptoms associated with their disabilities.

In her 2010 law review article entitled, Why Context Matters: Defining Service Animals Under Federal Law, Professor Rebecca Huss argued that there "are rational reasons to have an expansive definition of service animal" under federal law. ${ }^{210}$ In the alternative, she suggested "if there is a restrictive definition under the ADA, the broader protections under the FHA and ACAA should remain in place."211 This article agrees with Professor Huss's statement, that there are rational reasons to expand the definition of service animal. ${ }^{212}$ Further, this article agrees that "the broader protections under the FHA and ACAA should remain in place," but suggests that these broader protections are in jeopardy, and cannot be relied upon to protect the use of emotional support animals. ${ }^{213}$ Because of Senator Burr's bill, there is pending legislation that if passed, would force the ACAA to follow the restrictive definition of service animal and no longer allow for a broader definition that permits emotional support animals. ${ }^{214}$ Therefore, there would no longer be an avenue for a broader definition in the ACAA outside the scope of the ADA.

Further, Professor Huss stated that maybe "society is not ready to truly accept the premise of the $\mathrm{ADA}$, that all types of disabilities should be accommodated." 215 Senator Burr's bill indicates that she might be right about that. ${ }^{216}$ Nonetheless, her article was written in 2010 , over eight years ago. ${ }^{217}$ As the number of people with disabilities increases, ${ }^{218}$ one would hope that society would be more

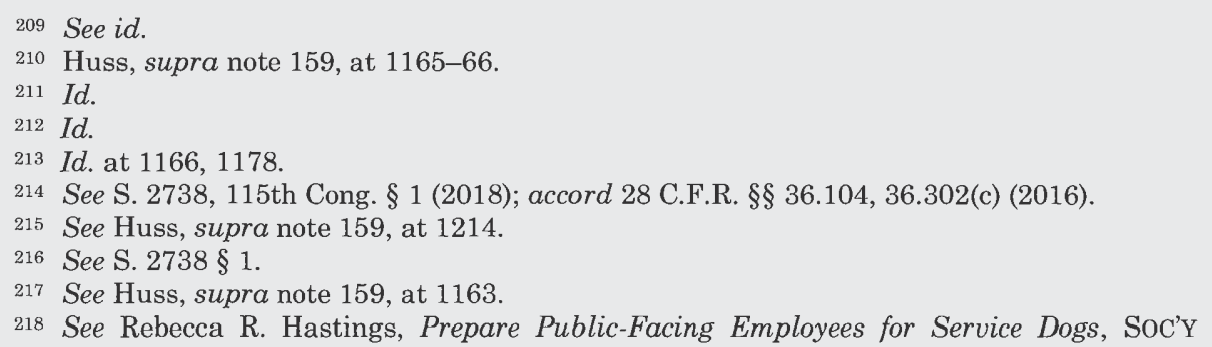


educated about and empathetic to the struggles endured by people with disabilities. There are some encouraging signs. A 2017 Kaiser Permanente poll showed that 73 percent of correspondents thought that psychiatric disabilities should be treated no differently than physical ones. ${ }^{219}$ Employers must take steps to educate public-facing employees who are the ones charged with helping to regulate the use of animals in places of public accommodation. ${ }^{20}$ This Article proposes to move society forward, not backward, by clarifying and creating a definition of service animal that would benefit all people with disabilities-both physical and mental.

Because the purpose of using a service animal or emotional support animal is to assist an individual with a disability in some manner, ${ }^{221}$ there should not be a hierarchy of which type of assistance is more important than another type of assistance. That is the issue created by the words, "work or tasks performed."222 If the law is written to focus on those words, then it alienates the individual who needs an animal to provide comfort, support, companionship or the like to manage his or her mental health issue. ${ }^{223}$ By alienating a certain group of individuals with disabilities, the stigma and discrimination against those individuals is perpetuated. ${ }^{224}$ Therefore, the definition

HuMAN Resource MGMT. (Nov. 30, 2009), https:/www.shrm.org/resourcesandtools/hrtopics/behavioral-competencies/global-and-cultural-effectiveness/pages/servicedogs.aspx; Lewis Kruas, 2016 Disability Statistics Annual Report, INST. ON DiSABILITY 7 (Jan. 2017), https://disabilitycompendium.org/sites/default/files/user-uploads/2016_AnnualReport.pdf.

219 Kaiser Permanente, National Poll: Mental Health Myths and Facts, FINDYOURWORDS.ORG, https://findyourwords.org/mental-health-myths-facts-national-poll/ (last visited Oct. 8, 2018).

220 See 28 C.F.R. $\S 36.302$ (c)(6) (explaining there are only two specific inquires that employees are permitted to ask people using service animals, and employees must be trained to understand how they should respond to customers in accordance with the law); see also Amy Viteri, Publix Says No Dogs in Grocery Carts, Including Service Pets, Local10.COM (July 28, 2018), https://www.local10.com/pets/publix-says-no-dogs-in-grocery-carts-including-service-pet $\mathrm{s}$ (explaining store policies have been created to manage people's use of service animals in these locations. For example, Publix has a policy for allowing only service animals in stores, but not in carts. This means that any animal other than a service animal is not allowed in the store, including emotional support animals); Reinaldo Llerena, Service Dogs Allowed in Stores, Restaurants. Fake Service Animals, However, Can Land You in Jail., MIAMI HERALD (Apr. 12, 2017), https://www.miamiherald.com/living/health-fitness/article144207564.html (highlighting that Target also has a service animal only policy, and the inquiry associated with determining whether an animal is a service animal. Even if stores have policies, and employees understand that only certain inquiries can be made, adding emotional support animal to the definition of service animal will require additional training for employees); Hastings, supra note 218 (discussing preparation of employees to deal with these types of situations).

221 See SERVICE ANIMALS: HouSING, supra note 12, at 2.

222 See 28 C.F.R. $\$ 36.104$.

223 Id.

224 See Daniel S. Goldberg, Introduction: On Stigma \& Health, 45 J.L. MED. \& ETHICS 475, 476-77 (2017). 
of service animal should include emotional support animal.

There is a need for service animals and emotional support animals to be well-behaved in public for a variety of reasons. ${ }^{225}$ For example, the backlash regarding exotic animals on airplanes, e.g., Dexter the peacock, stems from a fear that the public could be harmed by such an animal in an enclosed space, such as an airplane. ${ }^{226}$ There is a balance between an individual's use of a service animal and the public's need to be safe from harm. ${ }^{227}$ Additionally, this new broader definition should be carefully tailored to address the concerns of those who use service animals while not excluding those who need emotional support. This Article agrees with the advocacy groups including the Psychiatric Service Dog Partners, Guide Dog Foundation for the Blind, Open Doors Organization, National Multiple Sclerosis Society, and Guide Dog Users, Inc., who have proposed to limit the types of animals included in the definition. ${ }^{228}$ Although this Article agrees with drawing the line when it comes to which animals are included, it remains that deciding which animals are included or excluded will not be an easy task. Any definition should leave space to expand which animals are allowed as the science changes. The starting point, as indicated by the five named advocacy groups, includes dogs, cats, and rabbits. ${ }^{229}$

This Article agrees with the many commentators who argue that fraud is an issue that needs to be addressed. ${ }^{230}$ This Article, however, argues that the fear of people fraudulently claiming that their animals are either service animals or emotional support animals cannot stop us from allowing the use of these animals by people who need them as part of their daily lives. As noted above, mental health professionals, such as psychiatrists and psychologists, have their own internal regulations to help address the issue of fraud. ${ }^{231}$ Instead,

${ }^{225}$ See Jacquie Brennan \& Vinh Nguyen, Service Animals and Emotional Support Animals, ADA NAT'L NETWORK (2014), http://adata.org/publication/service-animals-booklet.

226 See Kate Gibson, Southwest Airlines Bans Exotic Emotional Support Animals, CBS NEWS (Aug. 15, 2018), http://cbsnews.com/news/southwest-airlines-bans-exoitc-emotional-support-an imals/.

227 The public fear associated with animals behaving in a harmful manner is addressed by the "direct threat" defense. See 28 C.F.R. $\S 36.208$. The "direct threat defense, which allows the exclusion of a service animal if the animal exhibits unwarranted or unprovoked violent behavior or poses a direct threat." 28 C.F.R. pt. 36, app. A; see also Rose v. Springfield-Greene Cty. Health Dep't, 668 F. Supp. 2d 1206, 1216 (W.D. Mo. 2009) (stating that accommodations are not required when there is an unpredictable risk of violent behavior by a monkey).

228 See Traveling by Air With Service Animals, 83 Fed. Reg. 23832, 23,836 (proposed May 23, 2018) (to be codified at 14 C.F.R. pt. 382).

229 Id.

230 See id. at 23,832; AM. VETERINARY MED. ASs'N, supra note 94, at 2-3.

231 See Younggren et al., supra note 98, at 258. 
the focus should be on drafting laws that are clearly written, so that enforcement would be less of an issue. The topic of punishments or penalties associated with this type of fraud needs to be addressed because Senator Burr's bill has a criminal penalty piece in it, but that is not the focus of this Article. ${ }^{232}$

Therefore, this Article proposes that the ADA's definition of service animals should be amended to include emotional support animals, specifically identifying allowed animals and requiring minimum behavior standards, and fraud avoidance. Other avenues for protection of people using emotional support animals are not working, so it is necessary to make this change. ${ }^{233}$

\section{CONCLUSION}

Do not let the peacock trying to board an airplane distract from the real issue at hand.

People who experience mental health issues and need emotional support animals in public places, including on mass transit, to participate in society, should not be denied this accommodation based on fear that some people may fraudulently claim that their pets are emotional support animals.

The ADA's narrow approach to defining service animals only protects a certain group of people with disabilities using a certain type of animal, dogs who perform work or tasks associated with the person's disability. This narrow approach does not consider the thousands of people who use emotional support animals to alleviate or mitigate the symptoms associated with their mental health issues. ${ }^{234}$ The ADA's promise was to bring people with disabilities into the public sphere; ${ }^{235}$ without expanding the definition, those with mental health issues will remain stuck behind closed doors. To provide parity, it is necessary to include emotional support animals within that definition.

Further, the FHA and ACAA have provided protection and

232 See S. 2738, 115th Cong. $§ 1$ (2018); Lee, supra note 113, at 326; Younggren et al., supra note 98 , at 258 .

233 See Andy Steiner, Animals Can Provide Emotional Support and Service, but the Two Jobs are Distinct, MinNPosT (July 16, 2018), https://www.minnpost.com/mental-health-addition/201 8/07/animals-can-provide-emotional-support-and-service-two-jobs-are-disti/.

234 See e.g., Samantha Bomkamp, Emotional Support Animals-from Dogs to Peacocks, Real or Fake-Present Challenges for Businesses, CHICAGO TRIBUNE (Feb. 9, 2018), http://www.chica gotribune.com/business/ct-biz-emotional-support-animals-20180211-story.html.

235 See ADA-Findings, Purpose, and History, ADA NAT'L NETWORK, http://www.adaanniver sary.org/findings_purpose, (last visited Nov. 4, 2018). 
accommodations for people using emotional support animals, ${ }^{236}$ but that protection is in jeopardy. If Senator Burr's bill is passed, and the ACAA is restrained from allowing emotional support animals to be service animals under the ACAA, then people with mental health issues will once again be stigmatized and treated differently from people with physical disabilities. In a time where there is increased acceptance of psychiatric disabilities, ${ }^{237}$ these bills promise to renew the stigma rather than remove it. Moreover, if the DOT decides to redraft the ACAA to exclude emotional support animals, then the same problem befalls people suffering from mental health issues who need their emotional support animals while in public.

Therefore, clear regulation is needed to ensure that all people with disabilities can use a service animal, including emotional support animals, if that animal will assist him or her with alleviating or mitigating the symptoms associated with his or her disability. If we legitimize the process of bringing an emotional support animal in public, including on mass transit, then we continue to take away the stigma of mental health issues. Let us open the door to the promise of extending the ADA to all those with disabilities. Parity is essential to accomplishing that goal.

236 See SERvice Animals: Housing, supra note 12; 14 C.F.R. 382.117(a), (e) (2009).

237 See Partick W. Corrigan \& Amy C. Watson, Understanding the Impact of Stigma on People with Mental Illness, WORLD PSYCHIATRY (Feb. 1, 2002), https://www.ncbi.nlm.nih.gov/p mc/articles/PMC1489832/. 